\title{
Timing of Circadian Activity in the Flying Squirrel in Central Finland
}

\author{
Timo TÖRMÄLÄ, Hannu VUORINEN \& Heikki HOKKANEN
}

Törmälä T., Vuorinen H. \& Hokkanen H., 1980: Timing of circadian activity in the flying squirrel in central Finland. Acta theriol., 25, 38: $461-474$ [With 4 Tables \& 3 Figs.].

Activity patterns of wild flying squirrels (Pteromys volans Linnaeus, 1758 were studied using an automatic ciné camera recording system in central Finland. The recording system is described and evaluated. The flying squirrels were generally nocturnal; only the lactating females and their young had an additional diurnal period in summer. Flying squirrels started their activity generally after sunset. Maximal phase-angle differences ( $4-6$ hours) occurred in winter. The flying squirrels returned to their nests in most cases before sunrise (in winter about 2 hours before). The midpoint of nocturnal activity was more than one hour after midnight in winter. The midpoint of diurnal activity in a lactating female was usually after noon. The mean time interval between the midpoints of her nocturnal and diurnal activity periods was ca. $12 \mathrm{~h} 40 \mathrm{~min}$. For flying squirrels living in the same nest, the onset of their activity was more closely synchronized than ends of their activity periods. The circadian activity rhythm was most precise in summer and least precise in winter. Factors affecting the timing of activity periods in flying squirrels are discussed briefly.

[Dept. Biol., Univ. Jyväskylä, 40100 Jyväskylä 10, Finland (TT, HV); Dept. Entomol., Cornell Univ., Ithaca, New York, U.S.A. (HH)]

\section{INTRODUCTION}

In field conditions most animals show clear 24-h rhythms. Circadian rhythmicity is entrained and controlled by periodic environmental factors called Zeitgebers, which synchronize the rhythm in $24 \mathrm{~h}$ cycles. The most powerful Zeitgeber appears to be the daily light-dark (LD) cycle. Numerous laboratory studies (e.g., A s c h of f, 1960; D e C o u r s e y, 1960, 1961; K r a m m, 1975, 1976) indicate that this rhythmicity is not only due to external stimuli or cues since animals in apparently constant conditions continue to exhibit a clear rhythmic behaviour for long periods of time (see also Brown, 1976; Edmunds, 1976).

Animals are designated nocturnal (night-active) or diurnal (dayactive) based on the time of their main activity period. Some voles may shift their activity type with season (E r k in a r o, 1961, 1969); and e.g., 
flying squirrels (Pteromys volans Linnaeus, 1758), may even exhibit both types simultaneously ( $\mathrm{T}$ ör mälä et al., 1980).

To be reasonable the circadian activity rhythm of an animal must be in phase with the periodic environment. In many of the mammals studied so far the onset and end of activity have been closely correlated with the supposed Zeitgeber (sunset and sunrise as reference points). In some species the phase relations are very definite. For example, the nocturnal American flying squirrel, Glaucomys volans, started and ended its activity at a constant distance from Zeitgeber (sunset and sunrise) throughout the year in a natural day-night cycle (D e C o u rs e y, 1960). Later studies have revealed great seasonal and latitudinal variation in the phase of many species. Some variations are so regular that several rules and theories have been proposed to describe and explain them (A s c h of f, 1969; D a a n \& A s c h of f, 1975).

Most of our present knowledge about circadian activity rhythms and their timing is derived from laboratory experiments. In spite of extensive studies in a great variety of light-dark schedules many questions remain still unanswered ( $\mathrm{P}$ a $\mathrm{lm}$ er, 1976).

The objective of this study was to describe the phase position and precision of circadian rhythms in wild flying squirrels in central Finland as affected by season and, to a lesser extent, by sex and age. The general activity pattern ( $\mathrm{Hokkanen}$ et al., 1977), development of outdoor activity in young flying squirrels ( $\mathrm{T}$ ö $\mathrm{r}$ äl ä et al., 1978) and activity-time strategy ( $\mathrm{T}$ ö $\mathrm{r} \mathrm{m}$ äl ä et al., 1980) have been discussed in previous publications.

\section{MATERIAL AND METHODS}

We began recording the activity of flying squirrels on 7 November 1974 in Muurame $\left(62^{\circ} 10^{\prime} \mathrm{N}, 25^{\circ} 30^{\prime} \mathrm{E}\right)$, central Finland. The main study nests was monitored continuously until April 1978. During this study the nest which was situated in a woodpeckers hole in a tall spruce was occupied continuously by $1-4$ squirrels. The habitat was mature mixed forest dominated by spruce and alder. Additional material was gathered from three other nests located near by.

After some experimentation with event recorders, a reliable ciné camera system was developed for recording (Fig. 1). The system worked during cold winters (min. ca. $-35^{\circ} \mathrm{C}$ ) and also during current cuts due to the accumulator.

The film and the battery in the electrical clock lasted for months. Each record (single colour picture) provided the following data: date, precise time of day, direction of movement, and individual recognition, which in many cases was possible on the basis of differences in appearance or size of the squirrels inhabiting the nest. The use of simple event records in field studies may lead to severe misinterpretations because: Firstly, one cannot always judge from the event recorder data whether the animal is going to the nest or coming out, since it may 
release the switch several times in rapid succession. Secondly, if the nest is occupied by two or more individuals, a reliable interpretation often is practically impossible. Thirdly, other individuals of the same or other species may occasionally release the switch, and without a camera system these odd records cannot be excluded. For example, the main study nest was visited several times by a titmouse (Parus major), a pygmy owl (Glaucidium passerinum) and a bank vole (Clethrionomys glareolus).

Behaviour of the squirrels was divided into two activity states: active and inactive; animals were considered to be inactive when they were inside the nest and active when outside the nest. For studies of hole-dwelling animals this is the most convenient approach ( $\mathrm{Kram} \mathrm{m}, 1975)$.

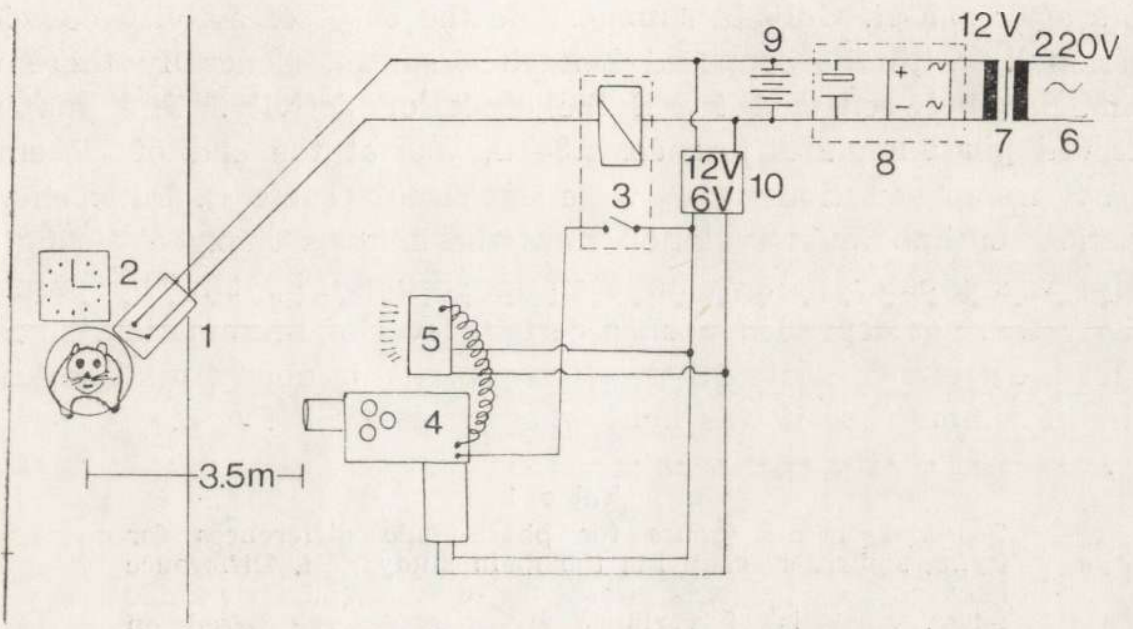

Fig. 1. Automatic recording system.

1. Capacitive approach switch (Seleprox KSS-3020), 2. Electrical clock with date display, 3. Reed relay, 4. Super $8-\mathrm{mm}$ ciné camera that takes single shots (Canon Auto Zoom 814 eletronic), 5. Flash unit, 6. Line voltage $220 \mathrm{~V} / 50 \mathrm{~Hz}$, 7. Transformer, 8. Rectifier, 9. Accumulator, 10. Transformer.

For statistical calculations the calendar year was divided into 37 ten day periods (the final period and the last third of February were shorter). Periods that included reliable information for five days at least were used in analyses. All figures and tables are based on these means for ten day periods unless stated otherwise. Since individual recognition was not always possible the emergence of the first individual from the nest and return of the last to the nest were used in calculations of the phase relations and precision of the rhythm. The squirrels occasionally left the nest for a couple of minutes outside the actual activity period to urinate or defecate. These trips were omitted from the data. For practical reasons time is given in hours and decimals. 


\section{RESULTS}

\subsection{Phase of Nocturnal Activity}

The flying squirrels had a nocturnal activity component throughout the year. Only lactating females and their outdoor active young were nocturnal and diurnal (see $\mathrm{T}$ ö $\mathrm{r} \mathrm{m}$ äl ä et al., 1980).

The phase relations of the nocturnal activity periods are desicribed (Fig. 2) using the three most commonly used parameters: $\psi_{0}$ (time at sunset minus time at onset of nocturnal activity), $\psi_{e}$ (time at sunrise minus time at end of nocturnal activity), and $\psi_{\mathrm{m}}\left(1 / 2\left(\psi_{\mathrm{o}}+\psi_{\mathrm{e}}\right)\right)$. Accordingly $\psi_{0}=-1.50 \mathrm{~h}$ means that the squirrel left the nest one and a half hours after sunset. Only in summertime the onset of activity coincided occasionally with the supposed Zeitgeber, sunset. Generally there was a time lag between sunset and the onset of activity. The maximal observed phase-angle difference, $6.34 \mathrm{~h}$, was at the end of December 1976. Seasonal variations in $\psi_{0}$ were significant (Table 1). Between-year variation (or individual variation since the animals changed during the study) was greater in autumn than in spring (Fig. 2). The onset of activity was not depended upon a certain level of illumination, since in winter the squirrels started their activity period in almost total darkness, while in summertime it was light when they left the nest.

\section{Table 1}

Seasonal means (hours for phase-angle differences for flying squirrels occupying the main study nest. Difference between $-\psi_{\mathrm{o}}$ and $\psi_{\mathrm{e}}$ were tested using a two-tailed $t$-test. Analysis of variance and $t$-tests were based on ten-day means $(n=80)$.

\begin{tabular}{lcccr}
\hline Season & $\psi_{\mathrm{o}}$ & $\psi_{\mathrm{e}}$ & t-test & $\psi_{\mathrm{m}}$ \\
\hline Spring & -2.40 & 2.23 & N.S. & -0.08 \\
Summer & -0.34 & 0.63 & $P<.05$ & 0.16 \\
Autumn & -0.83 & 0.88 & N.S. & 0.02 \\
Winter & -4.85 & 2.14 & $P<.001$ & -1.37 \\
$F_{3,79}$ & 67.51 & 51.81 & - & 25.20 \\
& $P<.001$ & $P<.001$ & & $P<.001$ \\
\hline
\end{tabular}

The flying squirrels usually returned to the nest before sunrise. Only the lactating female, which in 1975 bred early returned to the nest after sunrise. The maximal $\psi_{\mathrm{e}}(3.32 \mathrm{~h})$ occurred at the beginning of April 1976. This was only about half the absolute value for maximal $\psi_{\mathrm{o}}$. Besides having a smaller range also the seasonal means of $\psi_{\mathrm{e}}$ were smaller than those of $\psi_{\mathrm{o}}$. In winter the difference was especially clear (Tablle 1). Year-to-year (or individual) variation in $\psi_{\mathrm{e}}$ was less pronounced than in $\psi_{\mathrm{o}}$. 

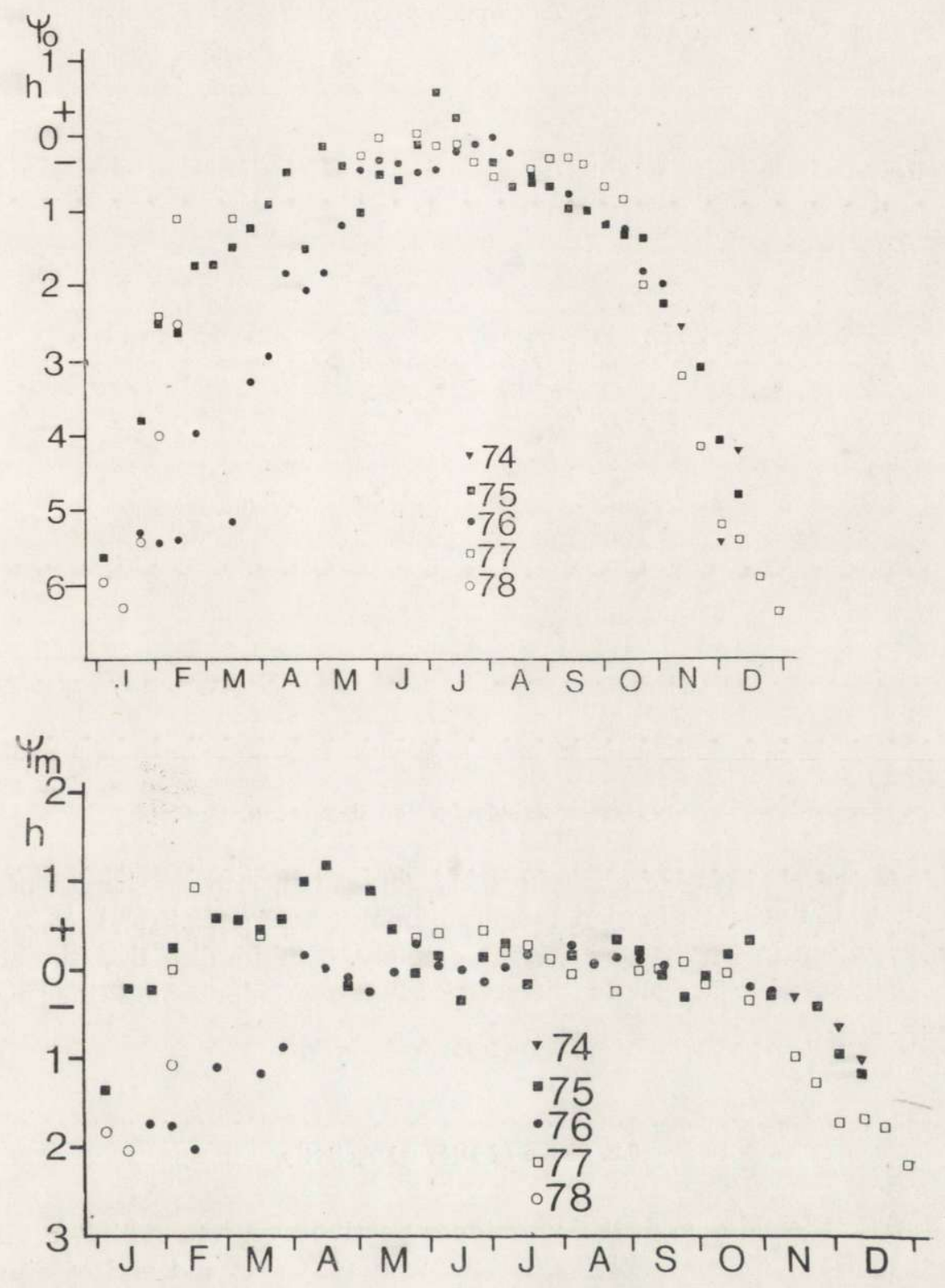

Fig. 2. Continued on page 466

The overall phase $\left(\psi_{\mathrm{m}}\right)$ of activity was closely synchronized with the reference point, midnight, in the summer half of the year, while in winter the midpoint of activity was after midnight. Ten day means of $\psi_{\mathrm{m}}$ varied from $-2.18 \mathrm{~h}$ to $+1.19 \mathrm{~h}$, and the difference between seasons was significant (Table 1). Between-year variations in $\psi_{m}$ were greatest. in winter and early spring. 


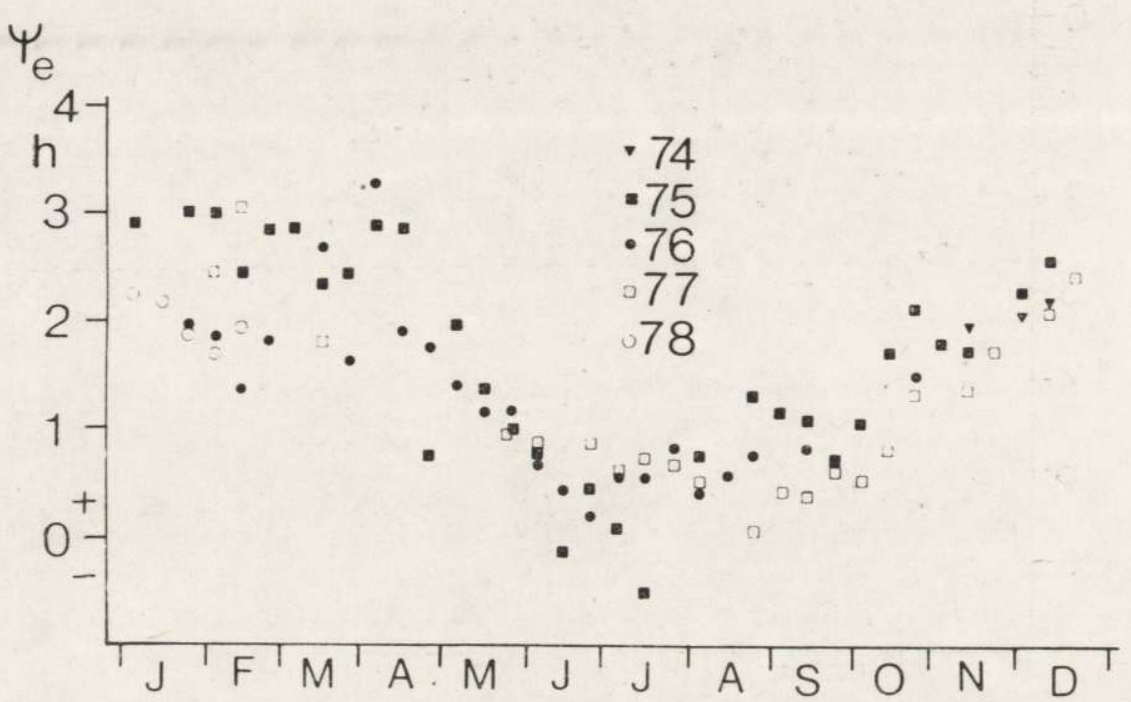

Fig. 2. Seasonal changes in phase-angle difference of activity onset $\left(\psi_{0}\right)$ midpoint $\left(\psi_{\mathrm{m}}\right)$ and end $\left(\psi_{\mathrm{e}}\right)$ in flying squirrels occupying the main study nest. The points represent values for ten day mean.

Phase parameters were significantly correlated with the length of the night. The linear regression models explained $68.7,13.2$ and $46.8 \%$ of the variation in $\psi_{\mathrm{o}}, \psi_{\mathrm{m}}$ and $\psi_{\mathrm{e}}$, respectively. This implies that the absolute values of phase-angle differences were greater when the nights were long.

\subsection{Phase of Diurnal Activity}

Nursing female and their outdoor active young exhibited both nocturnal and diurnal activity in summertime. Onset and end of diurnal activity can hardly be related to any environmental factors acting as possible Zeitgeber since outdoor visits generally took place between 1000 and 1400 hours when there were only minor changes in periodic factors. We compared, however, the midpoint of diurnal activity with the solar midday. Especially in 1976 the midpoint of diurnal activity was later than the noon (Table 2). The mean interval between the midpoints of nocturnal and diurnal activity periods was $12.76 \mathrm{~h}$ in 1975 and $12.54 \mathrm{~h}$ in 1976. No correlation was found between the $\psi_{\mathrm{m}}$ of nocturnal and diurnal activity periods $(r=0.08$, N.S.). 


\subsection{Individual Variation in the Phase}

During the winter of $1975-76$ the main study nest was occupied by a male and female. In early winter the female usually started her activity slightly before the male $(\bar{x}=1.25 \mathrm{~min} ., \mathrm{n}=23)$. Subsequently the female returned to the nest a little later $(\overline{\mathrm{x}}=2.55 \mathrm{~min} ., \mathrm{n}=17)$ than the male. These differences were not statistically significant. In early spring 1976 for 38 days when we could recognize them individually the female and the male were each first to leave the nest an equal number of times $(n=19)$. Also in cases when the nest was occupied by two or more in-

Table 2

Phase-angle difference between solar midday and the midpoint of diurnal activity in female flying squirrel in the main study nest. $\mathrm{n}$ indicates number of days on which reliable data were collected.

\begin{tabular}{|c|c|c|c|c|c|c|}
\hline Period & $\psi_{\mathrm{m}}$ & $\begin{array}{c}1975 \\
\text { S.D. }\end{array}$ & $\mathrm{n}$ & $\psi_{\mathrm{in}}$ & $\begin{array}{c}1976 \\
\text { S.D. }\end{array}$ & $\mathrm{n}$ \\
\hline 17.05.- & 0.07 & 0.59 & 4 & - & . - & - \\
\hline 20.05 - & -1.90 & 0.46 & 5 & - & - & - \\
\hline 30.05 - & 0.42 & 0.61 & 9 & - & - & 一 \\
\hline 09.06.- & 0.47 & 0.53 & 6 & - & - & - \\
\hline 19.06.- & -0.44 & 0.74 & 6 & -0.90 & 0.49 & 7 \\
\hline 29.06.- & -1.28 & 0.84 & 10 & -0.46 & 0.58 & 8 \\
\hline 09.07.-- & -2.12 & 0.50 & 3 & -0.43 & 0.78 & 10 \\
\hline 19.07.- & - & - & - & -0.85 & 0.55 & 10 \\
\hline 29.07.- & - & - & - & -0.46 & 0.62 & 8 \\
\hline
\end{tabular}

dividuals and individual recognition was not possible the absolute difference in phase was small. Therefore no differences due to sex were found in the onset and end of nocturnal activity outside the breeding season.

Since males and females live separately during the summer, their activity could not be compared directly. The main study nest was occupied in successive years by a female with young (1975-76) and a male (1977). During the time of lactation period the female started her nocturnal activity earlier and ended later than the male during the corresponding season.

Previously Törmälä et al., (1978) described development of activity time in young flying squirrels but did not give data about the phase nad precision of their activity rhytm. During the time the female and her young lived in the same nest the female started her activity earlier and ended it later than the young (Table 3). At the beginning of their outdoor activity the $\psi_{\mathrm{m}}$ of the young was somewhat earlier than that of the female. 
Table 3

Phase and precision of circadian activity rhythm in a female (f.) and her two young (j.) while occupying the main study nests in 1976. Values for the young are means for the two individuals.

\begin{tabular}{lrrrrrrrr}
\hline Period & & $\psi_{\mathrm{o}}$ & $\psi_{\mathrm{m}}$ & $\psi_{\mathrm{e}}$ & S.D.o & S.D.m & S.D.e & $\mathrm{n}$ \\
\hline 13.07.- & j. & -0.96 & 0.45 & 1.86 & 1.16 & 0.80 & 0.61 & 5 \\
& f. & 0.01 & 0.28 & 0.54 & 0.11 & 0.10 & 0.13 & \\
$19.07 .-$ & j. & -0.37 & 0.37 & 1.12 & 0.36 & 0.25 & 0.51 & 10 \\
& f. & -0.15 & 0.32 & 0.78 & 0.12 & 0.28 & 0.53 & \\
$29.07 .-$ & j. & -0.20 & 0.14 & 0.48 & 0.13 & 0.09 & 0.13 & 10 \\
& f. & -0.12 & 0.13 & 0.37 & 0.15 & 0.09 & 0.16 & \\
$08.08 .-$ & j. & -0.24 & 0.12 & 0.47 & 0.04 & 0.03 & 0.04 & \\
& f. & -0.22 & 0.16 & 0.53 & 0.14 & 0.04 & 0.15 & 6 \\
\hline
\end{tabular}

\subsection{Precison}

Precision of the circadian activity rhythm is most often expressed by standard deviation (or its reciprocal) of the phase-angle difference. In our analyses we used S.D., since the values of 1/S.D. were sometimes impractical, i.e. when S.D. is near zero, 1/S.D. has very high values

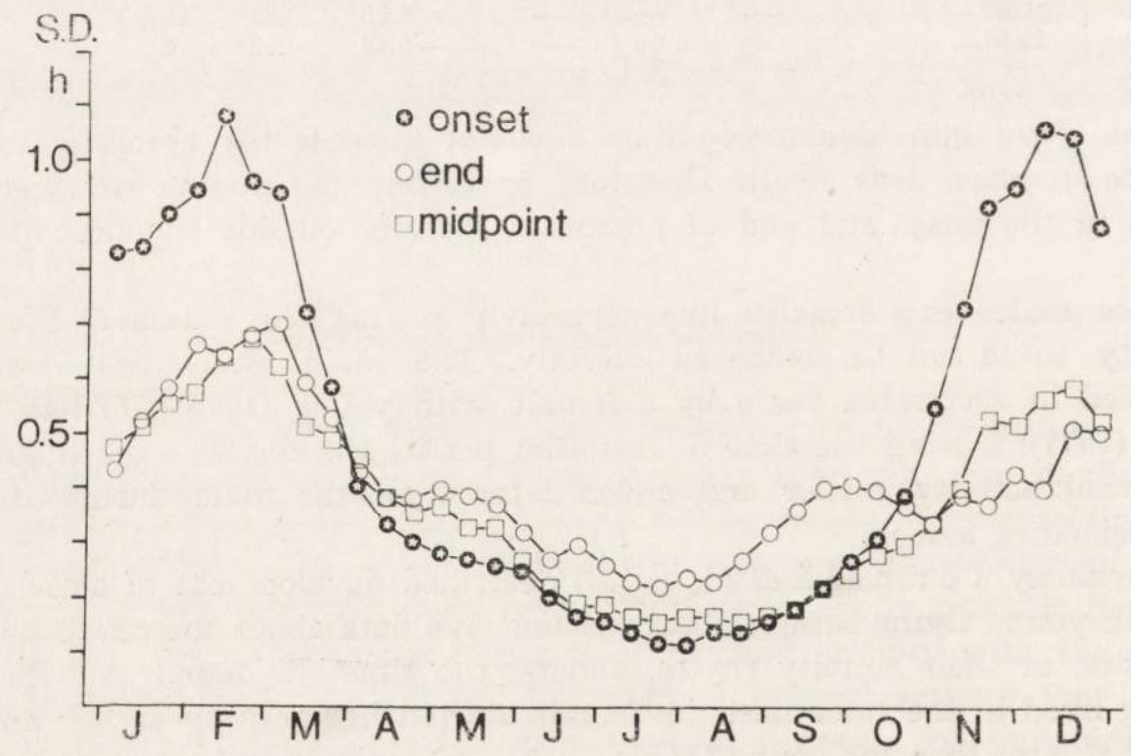

Fig. 3. Seasonal changes in the variability of phase-angle differences in the flying squirrels occupying the main study nest. The curves represent five-point moving average based on pooled data from all study years. 
making the scaling problematic. We calculated S.D. for each ten day period; low S.D. indicates that the phase relation within a given period was stable (precise).

The original precision data showed greater variation and a less regular pattern than did the data for phase-angle difference. Data processing, however, revealed some regularities. The S.D. for all parameters $\left(\psi_{\mathrm{o}}\right.$, $\psi_{\mathrm{m}}$ and $\psi_{\mathrm{e}}$ ) were lowest in summer and highest in winter and early spring (Fig. 3, Table 4). This indicates to possible relationships between the phase-angle difference and precision. Precision and absolute value of the phase-angle difference correlated significantly. The linear regression models explained 35\% (onset), $10 \%$ (midpoint), and $19 \%$ (end) of the variation in precision.

Of the three variables, S.D. of $\psi_{\mathrm{m}}$ had smallest values for all seasons except in winter, when it slightly exceeded S.D. $\psi_{\mathrm{e}}$. Since the values of S.D. $\psi_{\mathrm{m}}$ are affected by S.D. $\psi_{\mathrm{o}}$ and S.D. $\psi_{\mathrm{e}}$ it was not compared statistically with them. The onset of activity was more precise in summer and autumn and less precise in spring and winter than the end of

Table 4

Seasonal means for precision (S.D. of phase-angle differences, hours) of circadian activity rhythm in flying squirrels occupying the main study nests. Material and tests same as in Table 1.

\begin{tabular}{lcccc} 
Season & S.D.o & S.D.e & t-test & S.D.m \\
\hline Spring & 0.86 & 0.58 & $P<.05$ & 0.56 \\
Summer & 0.31 & 0.37 & N.S. & 0.26 \\
Autumn & 0.17 & 0.27 & $P<.001$ & 0.15 \\
Winter & 0.73 & 0.42 & $P<.01$ & 0.45 \\
F3, 79 & 16.00 & 11.16 & - & $P<.001$ \\
& $P<.001$ & $P<.001$ & & $P$ \\
\hline
\end{tabular}

activity (Table 4). Seasonal variation was significant for all parameters, and it was greatest for S.D.

In young flying squirrels the precision of activity rhythms developed rapidly and achieved the same level of precision as the female in a few weeks (Table 3 ).

\subsection{Synchronization Between Individuals}

In all cases when the nest was occupied by two or more squirrels, their times of leaving the nest were more synchronized than their return into it. For example, in autumn 1975 when a male and a female lived together the mean absolute time difference in their emergence 
from the nest was $0.03 \mathrm{~h}$ and that for return was $0.23 \mathrm{~h}(t=6.82, P<.001$, d.f. $=78$ ). The same phenomenon was observed for the juveniles occupying the nest in summer $1976(t=3.17, P<.001$, d.f. $=32)$. The best explanation is assuming that the first individual to become active in the nest stimulates the others, but the time of return reflects more individual properties of the circadian activity rhythm.

\section{DISCUSSION}

\subsection{Phase}

Da a n \& Aschoff (1975) studied timing of circadian activity rhythm as affected by season and latitude in several nocturnal and diurnal species and summarized the information gathered so far. The seasonal changes in phase relations and precision were neglible in the American flying squirrel, Glaucomys volans, in southern Germany but very distinct in Kuusamo near the Artic Circle. Their results with Glaucomys differ in many respects from ours with Pteromys. One trivial reason for this is the fact that Kuusamo is situated about $4^{\circ}$ to the North of our study area. In Pteromys $\psi_{\mathrm{e}}$ varied less with season than did $\psi_{\mathrm{o}}$. The reverse was, however, found in Glaucomys; the fifth "circadian rule" formulated by A s c h of f \& W e ver (1962) also states that $\psi_{\mathrm{o}}$ is less subject to seasonal variation than $\psi_{\mathrm{e}}$. This rule has been shown to be invalid for many diurnal species and now for the predominately nocturnal Pteromys.

The third commonly used measure of phase-angle difference between the activity rhythm of the animals and the Zeitgeber is $\psi_{\mathrm{m}}$, which is the time interval between the midpoint of activity and solar midnight in nocturnal animals (see A s ch off, 1964, 1965). $\psi_{\mathrm{m}}$ is not an independent measure since it is simply the arithmetic mean of $\psi_{\mathrm{o}}$ and $\psi_{\mathrm{e}}$. Generally it has been observed that $\psi_{\mathrm{m}}$ undergoes only minor seasonal changes even at high latitudes, because of the mirror-image changes in $\psi_{\mathrm{o}}$ and $\psi_{\mathrm{e}}$. Even though the range changes is small, the seasonal pattern has in most cases been clear ( $\mathrm{D}$ a a n \& A s c h of $\mathrm{f}, 1975$ ). According to the first "circadian rule ", nocturnal mammals should have a maximum phase lead in winter ( $\psi_{\mathrm{m}}$ has a high positive value). The results of $\mathrm{D}$ a a n \& A s h off (1975) for captive golden hamsters (Mesocricetus auratus) and American flying squirrels support this rule, while our results show it to be invalid for wild flying squirrels (Fig. 2, Table 1).

The flying squirrel, as well as the captive test animals of $\mathrm{D}$ a a $\mathrm{n}$ \& A s c h of $f$ (1975) at high latitudes, showed rigid seasonal variation in $\psi_{\mathrm{o}}$ and $\psi_{\mathrm{e}}$, meaning that the activity during different seasons starts and 
ends at different intervals from sunset and sunrise and also at different levels of illumination. This indicates that a certain level of light intensity cannot act as the pacemaker for the circadian activity rhythm throughout the year. In winter the flying squirrels started and ended their activity in almost total darkness while in midsummer they were active during the relatively light nights.

Like the proportional effect, also the differential effect (for terms see A sch of f, 1960; Da a n \& A s ch of f, 1975) of Zeitgeber cannot be of constant importance throughout the year since in wintertime the squirrels were not active in dawn or dusk. This implies that endogenous factors may be strongly involved. According to e.g. D a a $\mathrm{n}$ A s $\mathrm{ch}$ of $\mathrm{f}$ (1975), Zeitgeber seem to have the strongest effect when activity is started and ended during twilight, as was the case for flying squirrels during summer and early autumn. The precision of the rhythm was also greatest at that time. Later, probably due to ecological factors (see Törmälä et al., 1980) the activity time became quite rapidly shorter than the night; consequently, the onset and end of activity glided apart from sunrise and sunset (Zeitgeber cues). The phase relation is obviously maintained during the winter half of the year mainly by the endogenous component, which had been programmed and entrained during the summer and early autumn. This is supported by the fact that the time of onset and end of activity varied less during winter than did the timeof sunset and sunrise. We also observed that the circadian rhythm during winter was not exactly 24 -h long, which caused shifth in phase. The design of this study does not permit discussion of the role of other physical factors that might act as possible Zeitgebers (B row n, 1978).

The flying squirrels had a bimodal pattern of activity in winter (see T örmäl ä et al., 1980), and in summer the activity of the reproducing female was split into nocturnal and diurnal components about 12 hours apart. The midpoints of nocturnal and diurnal activity periods seemed not to have a common frequency (midpoints were not correlated). These observations fit to the characteristics of the two-oscillator system in animals proposed by Pittendrigh (1974). On the other hand the diurnal activity of the lactating female may have been timed by a completely different physiological system that of the nocturnal activity, e.g., hunger.

\subsection{Precision}

According to the fourth original "circadian rule « (As ch of $\mathrm{f} \& \mathrm{~W} c$ v e r, 1962), the onset of activity is more precise than the end of activity. Our data are controversial since in summer and autumn they conform. to the rule and in winter and spring deviate from it. 
Erkinaro (1972) found that the activity rhythm of the nocturnal Tengmalm's owl (Aegolius funereus) was more precise in spring and autumn than in winter and summer. This is in accordance with the two-modal pattern with minimal precision in winter and summer found in many nocturnal mammals at night in high latitudes. Possible explanations for the general bimodal pattern in precision are according to $\mathrm{D}$ a a $\mathrm{n}$ \& A sch off (1975): 1) The endogenous clock of the animal can be assumed to be least precise near the summer and winter solstices (see also Erkinaro, 1972), 2) That the phase control of precision might be better with stronger Zeitgebers, and that Zeitgeber strength decreases towards summer and winter solstices, and 3) The direct action of light on the overt rhythm causing positive or negative masking (A s ch of $\mathrm{f}$, 1960; Hof $\mathrm{fmann}, 1969$ ) is obviously at minimum in spring and autumn since activity period begins and ends in twilight.

In flying squirrels the inaccuracy of the activity rhythm in winter is most probably due to very weak Zeitgeber strength because of great phase-angle difference in onset and end of activity periods. In winter the activity starts and ends in darkness. In summer the phase-angle difference is small, the amplitude of LD-cycle was probably great enough to allow a strong Zeitgeber effect, and the rhythm is markedly accurate in summer compared to results with nocturnal mammals and birds at higher latitudes (Erkinaro, 1972; Daan \& A s choff, 1975).

Acknowledgements: The study was financially supported by the Finnish Cultural Foundation. Dr. Jussi Viitala kindly read the manuscript and Dr. Joann v. Weissenberg revised the English.

\section{REFERENCES}

1. Aschoff J., 1960: Exogenous and endogenous components in circadian rhythms. Cold Spring Harb. Symp. quant. Biol., 25: 11-28.

2. A s ch off J., 1964: Die Tagesperiodik licht- und dunkel-aktiver Tiere. Rev. suisse Zool., 71: 528-558.

3. A sch off J., 1965: The phase-angle difference in circadian periodicity. [In: "Circadian clocks«, Ed. Aschoff J.]. North Holland: 262-276.

4. A schoff J., 1969: Phasenlage der Tagesperiodik in Abhängigkeit von Jahreszeit und Breitengrad. Oecologia, 3: 125-165.

5. A s ch off J. \& Wever R., 1962: Beginn und Ende der täglichen Aktivität freilebender Vögel. J. Orn., 103: 2-27.

6. Brown F. A. Jr., 1976: Evidence for external timing of biological clocks. [In: "An Introduction to Biological Rhythms«, Ed. Palmer J. D.]. Academic Press: 209-279.

7. Daan S. \& Asch off J., 1975: Circadian rhythms of locomotor activity in captive birds and mammals: their variations with season and latitude. Oecologia, 18: 269-316. 
8. De C oursey P. J., 1960: Phase control of activity in a rodent. Cold Spring Harb. Symp. quant. Biol., 25: 49-55.

9. DeC oursey P. J., 1961: Effect of light on the circadian activity rhythm of the flying squirrel, Glaucomys volans. Ztschr. vergl. Physiol., 44: 331-354.

10. Edmunds L. D. Jr., 1976: Models and mechanisms for endogenous timekeeping. [In: »An Introduction to Biological Rhythms«, Ed. Palmer J. D.]. Academic Press: $280-363$.

11. Erkinaro E., 1961: The seasonal changes of activity of Microtus agrestis. Oikos, 12: 157-163.

12. Erkinaro E., 1969: Der Phasenwechsel der lokomotorischen Aktivität bei Microtus agrestis (L.), M. arvalis (Pall.), und M. oeconomus (Pall.). Aquilo, Scr. Zool., 8: $1-31$.

13. Erkinaro E., 1972: Precision of the circadian clock in Tengmalm's owl, Aegolius funereus (L.), during various seasons. Aquilo, Ser. Zool. 13: 48-52.

14. H of $\mathrm{m}$ a $\mathrm{n} n \mathrm{~K}$., 1969: Die relative Wirksamkeit von Zeitgebern. Oecologia, 3: $184-206$.

15. Hokkanen H., Törmälä T. \& Vuorinen H., 1977: Seasonal changes in the circadian activity of Pteromys volans L. in central Finland. Ann. Zool. Fennici, 14: 94-97.

16. $\mathrm{Kramm} \mathrm{K}$. R., 1975: Entrainment of circadian activity rhythms in squirrels. Amer. Natur., 109: 379-389.

17. $\mathrm{Kramm} \mathrm{K}$. R., 1976: Phase control of circadian activity in the antelope ground squirrel. J. interdiscipl. Cycle Res., 7: 127-138.

18. Palmer J. D. (ed.), 1976: An Introduction to Biological Rhythms. Academic Press: $1-375$.

19. Pittendrigh C. S., 1974: Circadian oscillations in cells and the circadian organization of multicellular system. [In: "The neurosciences; third study program«, Ed. Schmitt]. MIT Press: 437-458.

20. Törmälä T., Hokkanen H. \& Vuorinen H., 1978: Outdoor activity of young flying squirrel, Pteromys volans (Linné, 1758), in central Finland. Säugetierkdl. Mitt., 26: 250-251.

21. Törmälä T., Hokkanen H. \& Vuorinen H., 1980: Activity time of the flying squirrel, Pteromys volans, in central Finland. Ztschr. Säugetierkde, 45: $225-234$.

Accepted, May 12, 1980.

Timo TORMÅLA, Hannu VUORINEN i Heikki HOKKANEN

\section{OKOEODOBOWA AKTYWNOSC POLATUCH W CENTRALNEJ FINLANDII}

\section{Streszczenie}

Badano wzorzec aktywności i jego synchronizację u polatuch, Pteromys volans Linnaeus, 1758, używając automatycznej kamery fotograficznej (Ryc. 1). Polatuchy są zasadniczo zwierzętami nocnymi, a tylko karmiące samice i ich młode mają w lecie dodatkowy dzienny okres aktywności. Aktywność polatuch zaczyna się 
zazwyczaj po zachodzie słońca (Ryc. 2, Tabela 1). Maksymalne przesunięcie fazy ma miejsce zimą i wynosi 4-6 godzin. Polatuchy powracają do gniazd na ogół przed wschodem słońca; w zimie około 2 godzin przed wschodem. Szczyt aktywności nocnej przypada na godzinę pierwszą (zimą). Szczyt dziennej aktywności karmiących samic wypada zwykle tuż po dwunastej (Tabela 2). Przeciętna różnica między szczytami aktywności nocnej i dziennej wynosiła 12 godzin $40 \mathrm{~min}$. U polatuch żyjących w tym samym gnieździe, początek aktywności był bardziej zsynchronizowany niż jej zakończenie. Rytm aktywności dobowej młodych polatuch zaczyna się wykształcać $w$ miesiąc po ich pierwszym wyjściu z gniazda (Tabela 3). Dobowy rytm aktywności jest najprecyzyjniejszy latem (Ryc. 3, Tabela 4). Omawiane są również czynniki wpływające na aktywność polatuch. 